\title{
Experimental investigation of photovoltaic thermal solar air collector with exergy performance comparison
}

\author{
Bahtiar $^{1}$, Muhammad Zohri' ${ }^{2}$, Ahmad Fudholi ${ }^{3}$ \\ ${ }^{2,3}$ Solar Energy Research Institute, The National University of Malaysia, Malaysia \\ ${ }^{1,2}$ Department of Physics Education, Universitas Islam Negeri Mataram, Indonesia
}

\begin{tabular}{|c|c|}
\hline Article Info & ABSTRACT \\
\hline Article history: & The integration of photovoltaic technology and solar air collector is named \\
\hline Received Jan 18, 2020 & pumping power to fan DC and produces thermal energy together with to \\
\hline Revised Mar 3, 2020 & cooling PV panel. The experimental with the indoor and outdoor evaluation \\
\hline Accepted Mar 17, 2020 & $\begin{array}{l}\text { of PVT solar air collector have been compared at the chosen solar intensity } \\
\text { of } 820 \mathrm{~W} / \mathrm{m} 2 \text {. The mass flow rate is range from } 0.01 \mathrm{~kg} / \mathrm{s} \text { to } 0.05 \mathrm{~kg} / \mathrm{s} \text {. }\end{array}$ \\
\hline Keywords: & $\begin{array}{l}\text { The exergy and efficiency exergy accuracy of PVT solar air collector } \\
\text { between indoor and outdoor evaluation are } 98.42 \%, 98.11 \% \text { respectively. }\end{array}$ \\
\hline Exergy efficiency & $\begin{array}{l}\text { The exergy and exergy efficiency comparison results indicated that the } \\
\text { indoor and outdoor investigation is suitable. }\end{array}$ \\
\hline Indoor & \\
\hline Outdoor & \\
\hline Photovoltaic thermal & \\
\hline Solar collector & $\begin{array}{r}\text { Copyright (C) } 2020 \text { Institute of Advanced Engineering and Science. } \\
\text { All rights reserved. }\end{array}$ \\
\hline \multicolumn{2}{|l|}{ Corresponding Author: } \\
\hline $\begin{array}{l}\text { Muhammad Zohri, } \\
\text { Universitas Islam Neger } \\
\text { Jalan Gajah Mada No. } \\
\text { Email: zohri.ukm@gmai }\end{array}$ & Baru, Kota Mataram, Indonesia. \\
\hline
\end{tabular}

\section{INTRODUCTION}

Currently, increasing population and higher demands for energy have caused in the lack of predictable fossil oils. The fossil oils produced huge contamination and environmental issue. Renewable energy such as solar energy is the perfect substitution for fossil oils. Solar energy interests many clients because of fresh, unexhausted, low-priced, simply accessible. [1-3]. Solar energy produced thermal and electrical energy. Thermal energy is usually generated from solar collector and electrical energy is generated from photovoltaic technology. The hybrid of solar collectors and photovoltaic technology is called the photovoltaic thermal system (PVT). PVT system is usually developed by photovoltaic module, lining, material border, glass cover, absorber between channel tube of air or water fluid [4-11]. Many researchers have studied the PVT system with a theoretical and experimental approach. The configuration of the PVT system with photovoltaic panel and glass cover has been conducted by Slimani et al. [12]. This PVT system discovered a stimulating application for building and manufacturing practice. The additional glass cover improved the energy efficiency of PVT system. The hybrid PVT system between flat plate solar collector and Photovoltaic panel have been designed by Michael et al. [13] to assess the electrical and thermal efficiency with dissimilar projects.

The development and combination of the photovoltaic thermal system have been reviewed by Wu et al. [14]. Offering critical reviews is used to assess the character of the thermal absorber. The EVA based cover method is the best choice than current methods. Nazri et al. [15] established the theoretical approach with an energy analysis of photovoltaic thermal thermoelectric for solar air collectors. The complete efficiency of photovoltaic thermal integration with thermoelectric was higher than the photovoltaic module alone. The use of a V-groove absorber plate to evaluate thermal efficiency has been analyzed by Tadesse et 
al. [16]. The upsurge in the area of V-groove absorber increased energy performance than the flat plate solar collector.

Aristizabal et al. [17] have presented the building integrated photovoltaic system (BIPVS) with ideal control movement prototypical. The experimental investigation has been done in the Bogota condition, Colombia. The power flow has been affected by the meteorological data. For 2017, the power generation with the experimental investigation was $5.904 \mathrm{kWh} /$ year. Photovoltaic-thermoelectric generator (PV-TEG) hybrid system has been conducted by Ruzaimi et al. [18]. The excess heat from the PV module is absorbed by the integrated thermoelectric system. The maximum power from the number of TEG arrays reached 119 Watt. The performances of four photovoltaic technology are compared by Tadjer et al. [19]. The four technology of photovoltaic is monocrystalline, amorphous silicon, polycrystalline silicon, and cadmium telluride thin film. The best yield of evaluation is thin-film and amorphous silicon module for Saharan condition.

The simulation approach of the integrated hybrid stand-alone photovoltaic-diesel producer system has been done by Sulaiman et al. [20]. The project parameters and cost analysis have been simulated by HOMER software. The grades of simulation showed that photovoltaic and diesel generator integration is the best choice than the photovoltaic panel alone. The examination of photovoltaic efficiencies with different daily and monthly has been studied by Njok et al. [21] in Calabar, Nigeria. Two months for experimental are April and May with before noon, afternoon and full day time condition. The top-level of photovoltaic efficiencies is $77 \%$ and $73 \%$ at 12:30 for April and May respectively.

Lari and Sahin [22] informed that photovoltaic energy efficiency performance is $13.2 \%$. Khanjari et al. [23] reported that the exergy efficiency, energy efficiency, thermal efficiency, and overall PVT efficiency performance of the PVT system are 15\%, 10-13.7\%, 55\%, and 90\% respectively. the use of an aluminum refrigeration plate with a conventional and helical duct for PVT hybrid has been done by Salem et al. [24]. They resulted in the exergy efficiency of 11.1-13.5\%. the concentrating collector of the PVT system has been analyzed by Tripathi et al. [25] with the enviroeconomic and exergoeconomic analysis based on the energy and exergy approach. The examination was made by Syam and Tiwari [26] with a half-transparent photovoltaic panel collector. The environmental analysis with energy and exergy assessment of PVT mixedmode greenhouse dryer has been designed by Shyam et al. [27].

In recent years, the evolving PVT system technology has been developed extensively in numerous circumstances with different construction. The use of nanofluids as a cooling method for the PVT system [28-30] or phase change materials (PCM) method is the best performance than a representative PVT system commonly [31, 32]. The building integrated photovoltaic thermal system (BIPVT) has been reported acceptable relatively in the last time with energy and exergy evaluation [33-35]. Nevertheless, the performance comparison between the indoor and outdoor investigation of PVT system solar air collector is still less for exergy assessment. The objective of this study is to compare the exergy and exergy efficiency between indoor and outdoor investigation at The National University of Malaysia condition.

\section{RESEARCH METHOD}

In this study, the outdoor investigation of the photovoltaic thermal solar collectors has been conducted at The University of Malaysia's condition. The PVT system solar collector is developed by insulation, photovoltaic with monocrystalline of $100 \mathrm{~W}$, fan DC connected to channel, plate flat collector as shown in Figure 1. The indoor investigation of photovoltaic thermal solar collectors conducted at Laboratories of technology solar in The National University of Malaysia. Experimental with the indoor investigation under solar simulator with 45 halogen lamps, regulators to control the solar intensity of simulator, Anemometer DTA 4000 to control the mass flow rate, A pyranometer to control solar radiation, ADAM-4019 type to record temperature connected to computer software routinely as shown in our paper [36].

The maximum beneficial work of the system to achieve a thermal balance state is called the exergy of a system [37]. It characterizes the maximum size of energy to make beneficial work to the equilibrium condition [38]. Applying the first and second laws of thermodynamic is analyzed by exergy analysis. The exergy equation of the PVT system used the second law of thermodynamics [39]. The following equation calculates the exergy analysis as shown in Table 1 . Where the number of photovoltaic panels is $\mathrm{N}$, the solar intensity is $\mathrm{S}$, the sun temperature is $\mathrm{Ts}(\mathrm{Ts}=5777 \mathrm{~K})$, the ambient temperature is Ta, the inlet temperature is $\mathrm{Ti}$, the temperature output is To, temperature of photovoltaic panel is Tpv. 
Table 1. The equation of exergy analysis of PVT solar air collector

\begin{tabular}{lc}
\hline \multicolumn{1}{c}{ Performances } & Equations \\
\hline Exergy & $E x_{\text {input }}=E x_{\text {output }}+E x_{\text {Destruction }}$ \\
Exergy Efficiency & $\eta_{\text {exergy,PVT }}=E x_{\text {output }} /$ Ex $x_{\text {input }}$ \\
Exergy output (PVT) & $E x_{\text {output } / P V T}=E x_{P V}+E x_{\text {Thermal }}$ \\
Exergy input & $E x_{\text {input }}=A N S\left[1-\frac{4}{3}\left(\frac{T_{a}}{T_{s}}\right)+\frac{1}{3}\left(\frac{T_{a}}{T_{s}}\right)^{4}\right]$ \\
& $E x_{P V}=\eta_{P V} A S$ \\
Exergy Photovoltaic (PV) & \\
Exergy Thermal & $E x_{\text {thermal }}=\dot{m} C\left(T_{o}-T_{i}\right)\left(1-\frac{T_{a}+273}{T_{o}+273}\right)$ \\
Electrical efficiency & $\eta_{P V}=\eta_{o}\left[1-0.0045\left(T_{P V}-25\right)\right]$ \\
\hline
\end{tabular}

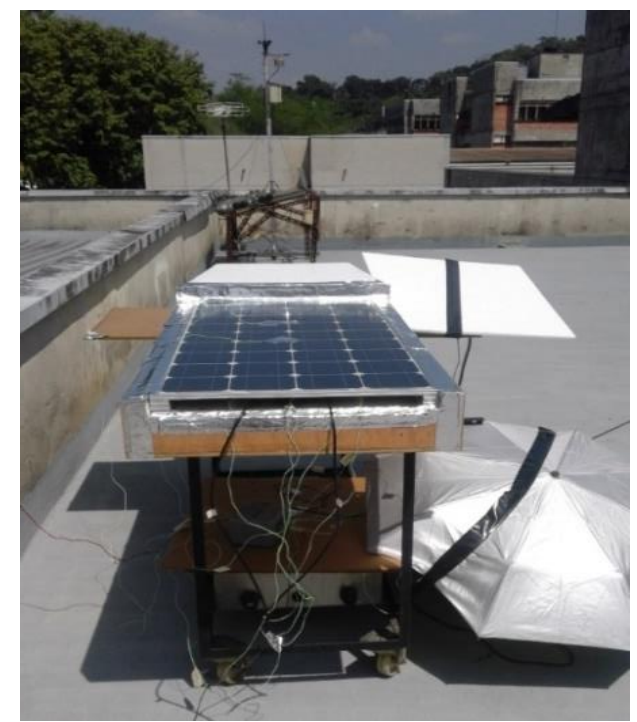

Figure 1. experimental with indoor investigation of PVT system air solar collector

\section{RESULTS AND ANALYSIS}

Figure 2 shows the grades of the mass flow rate versus the exergy performance of PVT solar air collectors at the solar intensity of $820 \mathrm{~W} / \mathrm{m} 2$. The PVT exergy is compared between indoor and outdoor investigation. The movement of PVT exergy has a similar movement, increases leisurely, and inclines between indoor and outdoor investigation. The maximum PVT exergy is 71.90 Watt with the indoor investigation. The minimum PVT exergy is 62.08 Watt with the indoor investigation. The grades of PVT exergy comparison show that the increase of the mass flow rate increases the exergy of the PVT solar air collector system.

Figure 3 shows the mass flow rate versus the exergy efficiency of PVT solar air collectors at the solar intensity of $820 \mathrm{~W} / \mathrm{m} 2$. The indoor investigation produced the exergy efficiency of $12.80-14.82 \mathrm{~W}$. the outdoor investigation produced the exergy efficiency of $12.89-14.26 \mathrm{~W}$. The movement comparison between the indoor and outdoor investigation of PVT exergy has a like movement, rises leisurely. Figure 3 displays that the increase in the mass flow rate increases the exergy efficiency of PVT solar air collectors.

Figure 4 shows the Average of PVT exergy with the outdoor investigation at the solar intensity of $820 \mathrm{~W} / \mathrm{m} 2$. For the outdoor investigation, the rate of the input, output and loss exergy is $485.05 \mathrm{~W}, 67.28 \mathrm{~W}$, and $417.77 \mathrm{~W}$, respectively and for the indoor investigation, the average of the input, output and loss exergy is $485.05 \mathrm{~W}, 68.21 \mathrm{~W}$, and $416.87 \mathrm{~W}$, respectively as shown in Figure 5.

Table 1 shows the accuracy comparison of PVT exergy and exergy efficiency of PVT solar air collector. The error of PVT exergy between indoor and outdoor investigation is $1.58 \%$ or accuracy of $98.42 \%$ and the error of exergy efficiency is $1.89 \%$ or accuracy of $98.11 \%$. From Table 2 show that the indoor investigation is suitable with the outdoor investigation. Table 3 displays the previous study's comparison with theoretical and experimental approaches. The present study is similar results with other studies with a range of $10 \%$ to $16 \%$. 


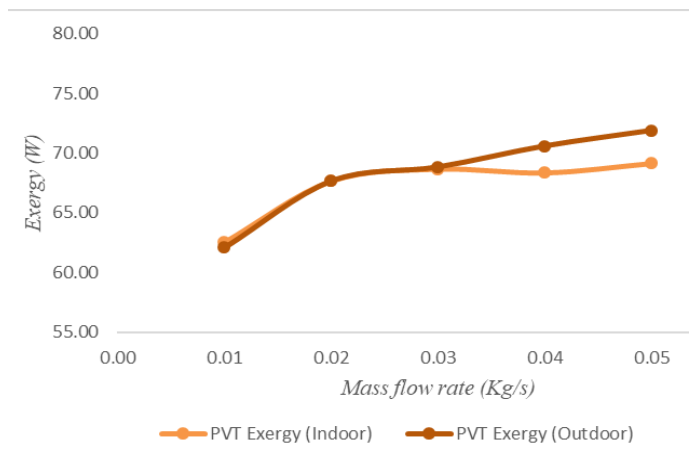

Figure 2. The mass flow rate versus PVT exergy with the indoor and outdoor investigation

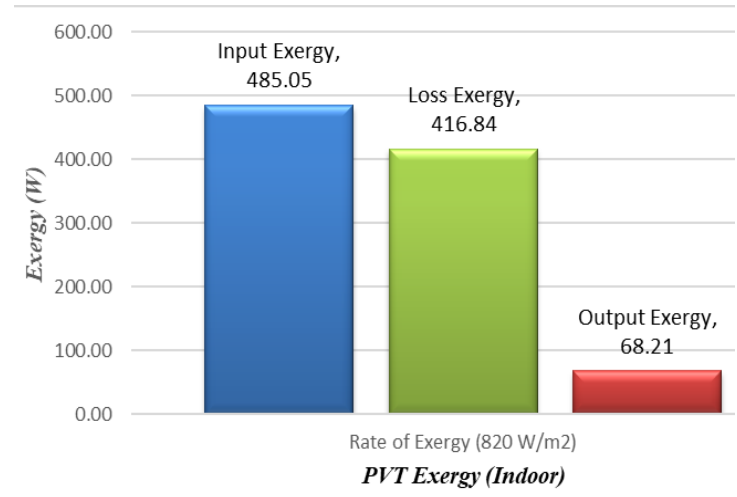

Figure 4. Average of PVT exergy with the outdoor investigation $(820 \mathrm{~W} / \mathrm{m} 2)$

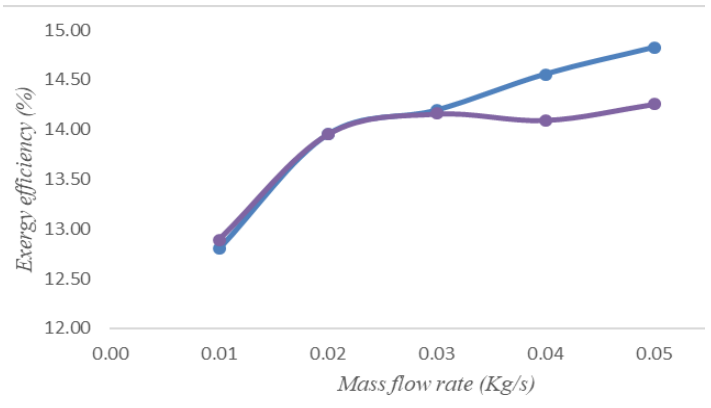

Figure 3. The mass flow rate versus PVT exergy efficiency with the indoor and outdoor investigation

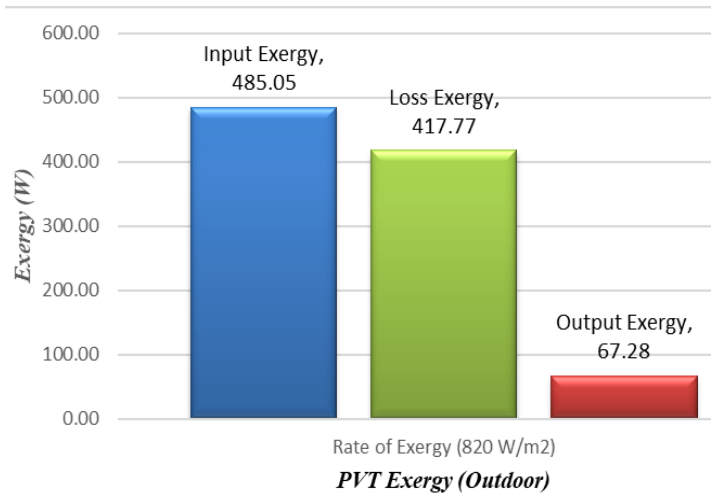

Figure 5. Average of PVT exergy with the indoor investigation $(820 \mathrm{~W} / \mathrm{m} 2)$

Table 2. The comparison of PVT exergy and exergy efficiency with the indoor and outdoor investigation

\begin{tabular}{cccccccc}
\hline$\dot{m}$ & \multirow{2}{*}{$\mathrm{S}\left(\mathrm{W} / \mathrm{m}^{2}\right)$} & \multicolumn{3}{c}{ PVT Exergy $(\mathrm{W})$} & \multicolumn{3}{c}{ Exergy efficiency $(\%)$} \\
$(\mathrm{Kg} / \mathrm{s})$ & & Indoor & Outdoor & Error & Indoor & Outdoor & Error \\
\hline 0.01 & 820 & 62.08 & 62.51 & 0.69 & 12.80 & 12.89 & 4.70 \\
0.02 & 820 & 67.66 & 67.67 & 0.02 & 13.95 & 13.95 & 0.61 \\
0.03 & 820 & 68.84 & 68.68 & 0.24 & 14.19 & 14.16 & 0.03 \\
0.04 & 820 & 70.59 & 68.37 & 3.16 & 14.55 & 14.09 & 2.26 \\
0.05 & 820 & 71.90 & 69.15 & 3.81 & 14.82 & 14.26 & 1.83 \\
Average & & 68.21 & 67.28 & 1.58 & 14.06 & 13.87 & 1.89 \\
\hline
\end{tabular}

Table 3. The exergy comparison with previous studies

\begin{tabular}{ccc}
\hline References & Study & PVT Exergy efficiency (\%) \\
\hline$[36]$ & Experimental and theoretical & $12.66-12.91$ \\
{$[40]$} & Experimental and theoretical & 14.80 \\
{$[41]$} & Experimental and theoretical & 8.66 \\
{$[42]$} & Experimental and theoretical & 16.3 \\
{$[43]$} & Experimental & 10.75 \\
Present study & Experimental & $12.80-14.82$ \\
\hline
\end{tabular}

\section{CONCLUSION}

The experiment of photovoltaic thermal solar air collector with the indoor and outdoor investigation has been conducted at The National University of Malaysia. The average exergy and exergy efficiency have been compared between indoor and outdoor investigation. The average error comparison of exergy and exergy efficiency performance is $1.58 \%, 1.89 \%$ respectively or the accuracy of exergy and exergy efficiency is $98.42 \%, 98.11 \%$ respectively. 


\section{REFERENCES}

[1] Y. Jia, G. Alva, G. Fang, "Development and applications of photovoltaic-thermal systems: A review". Renew Sustain Energy Rev, vol. 102, pp. 249-65. 2019.

[2] T.Ma, H. Yang, L. Lu, "Development of hybrid battery-supercapacitor energy storage for remote area renewable energy systems". Appl Energy, 2015.

[3] A. Modi, F. Bühler, JG. Andreasen, F. Haglind, "A review of solar energy based heat and power generation systems". Renew Sustain Energy Rev, vol. 67, pp. 1047-64, 2017.

[4] N.S. Nazri, et al., "Energy Economic Analysis of Photo-Voltaic-Thermal-Thermoelectric (PVT-TE) Air Collectors," Renewable and Sustainable Energy Review, vol. 92, pp. 187-97, 2018.

[5] N.S. Nazri, et al., "Mathematical Modeling of Photovoltaic Thermal-Thermoelectric (PVT-TE) Air Collector," International Journal of Power Electronics and Drive Systems (IJPEDS), vol. 9, no. 2, pp. 795-802, 2018.

[6] A. Fudholi, et al., "Review on Exergy and Energy Analysis of Solar Air Heater" International Journal of Power Electronics and Drive Systems (IJPEDS), vol. 9, no. 1, pp. 420-26, 2018.

[7] A. Fudholi, et al., "Review on Solar Collector for Agricultural Produce," International Journal of Power Electronics and Drive Systems (IJPEDS), vol. 9, no. 1, pp. 414-19, 2018.

[8] A. Fudholi, et al., "Primary Study of Tracking Photovoltaic System for Mobile Station in Malaysia," International Journal of Power Electronics and Drive Systems (IJPEDS), vol. 9, no. 1, pp. 427-32, 2018.

[9] C.N. Aisyah et al., "Kecekapan Pengumpul PV/T Menggunakan Pengumpul Terma Reka Bentuk Pilin (Efficiency of PV/T Collector Using Spiral Thermal Absorber Design)," Sains Malaysiana, vol. 47, no. 4, pp. 853-859, 2018.

[10] M. Zohri, et al., "Exergy Assessment of Photovoltaic Thermal with V-Groove Collector Using Theoretical Study". TELKOMNIKA (Telecommunication, Computing, Electronics and Control), vol. 16, no.2, pp. 550-57, 2018.

[11] M. Zohri, et al., "Photovoltaic Thermal (PVT) System with and Without Fins Collector: Theoretical Approach". International Journal of Power Electronics and Drive System (IJPEDS), vol. 8, no. 4, pp. 1756-63, 2017.

[12] M. E. A. Slimani, M. Amirat, I. Kurucz, S. Bahria, A. Hamidat, \& W.B. Chaouch, "A detailed thermal-electrical model of three photovoltaic/thermal (PV/T) hybrid air collectors and photovoltaic (PV) module: Comparative study under Algiers climatic conditions". Energy Conversion and Management, vol. 133, pp. 458-476, 2017.

[13] J. J. Michael, S. Iniyan, \& R. Goic, "Flat plate solar photovoltaic-thermal (PV/T) systems: a reference guide". Renewable and Sustainable Energy Reviews, vol. 51, pp. 62-88, 2015.

[14] J. Wu, X. Zhang, J. Shen, Y. Wu, K. Connelly, T. Yang, C. Chen, "A review of thermal absorbers and their integration methods for the combined solar photovoltaic/thermal (PV/T) modules". Renewable and Sustainable Energy Reviews, vol. 75, pp. 839-854, 2017.

[15] N. S. Nazri, A. Fudholi, M. H. Ruslan, K. Sopian, "Mathematical modeling of photovoltaic thermal-thermoelectric (PVT-TE) air collector". International Journal of Power Electronics and Drive Systems (IJPEDS), vol. 9, no. 2, pp. 795-802. 2018.

[16] M. Tadesse, "Design, modeling, and performance analysis of parallel flow double pass Vgroove solar air collector for preservation of onion in university students' cafeteria: Wolaita Sodo University". International Journal of Recent Development in Engineering and Technology, vol. 6, no. 6, pp. 1-12, 2017.

[17] A. J. Aristizabal, D. Ospina, M. Castaneda, S. Zapata, Banguero, "Optimal power flow model for building integrated photovoltaic systems operating in the andean range", Indonesian Journal of Electrical Engineering and Computer Science (IJEECS), vol. 16, no. 1, pp. 52-58.October 2019.

[18] A. Ruzaimi, S. Shafie, W.Z.W. Hassan, N. Azis, M. E. Ya'acob, E. Elianddy, "Temperature distribution analysis of monocrystalline photovoltaic panel for photovoltaic-thermoelectric generator (PV-TEG) hybrid application", Indonesian Journal of Electrical Engineering and Computer Science (IJEECS), vol. 17, no. 2, pp. 858-876, February 2020.

[19] S. A. Tadjer, A. Idir, F. Chekired, "Comparative performance evaluation of four photovoltaic technologies in Saharan climates of Algeria: Ghardaïa pilot station", Indonesian Journal of Electrical Engineering and Computer Science (IJEECS), vol. 18, no. 2, pp. 586-598, May 2020.

[20] S. I. Sulaiman, N. A. Ali, "Performance simulation of the integration of hybrid stand-alone photovoltaic system at Tuba Island", Indonesian Journal of Electrical Engineering and Computer Science (IJEECS), vol. 16, no. 1, pp. 107-115, October 2019.

[21] A. O. Njok, J. C. Ogbulezie, M. K. Panjwani, R. M. Larik, "Investigation of monthly variations in the efficiencies of photovoltaics due to sunrise and sunset times", Indonesian Journal of Electrical Engineering and Computer Science (IJEECS), vol. 18, no. 1, pp. 310-317, April 2020.

[22] M. O. Lari, A. Z. Sahin, "Design, performance and economic analysis of a nanofluid based photovoltaic/thermal system for residential applications". Energy Convers Manag, vol. 149, pp. 467-84. 2017.

[23] Y. Khanjari, F. Pourfayaz, A. B. Kasaeian, "Numerical investigation on using of nanofluid in a water-cooled photovoltaic thermal system". Energy Convers Manag, vol. 122, pp. 263-78. 2016.

[24] M. R. Salem, R. K. Ali, K, M. Elshazly. "Experimental investigation of the performance of a hybrid photovoltaic/thermal solar system using aluminium cooling plate with straight and helical channels". Sol Energy; vol. 157, pp. 147-56, 2017.

[25] R. Tripathi, G. N. Tiwari GN, V. K. Dwivedi. "Overall energy, exergy and carbon credit analysis of N partially covered Photovoltaic Thermal (PVT) concentrating collector connected in series". Sol Energy, vol. 136, pp. 260-7. 2016.

[26] G. N. S. Tiwari. "Analysis of series connected photovoltaic thermal air collectors partially covered by semitransparent photovoltaic module. Sol Energy. vol. 137, pp. 452-62, 2016. 
[27] G. N. S. Tiwari, O. Fischer, RK. IM. Al-Helal Mishra. "Performance evaluation of Nphotovoltaic thermal (PVT) water collectors partially covered by photovoltaic module connected in series: an experimental study". Sol Energy, vol. 34, pp. 302-13, 2016.

[28] S. Aberoumand, S. Ghamari, B. Shabani. "Energy and exergy analysis of a photovoltaic thermal (PV/T) system using nanofluids: An experimental study". Sol Energy, vol. 165, pp. 167-77, 2018.

[29] M. Sardarabadi, M. Hosseinzadeh, A. Kazemian A, M. Passandideh-Fard. "Experimental investigation of the effects of using metal-oxides/water nanofluids on a photovoltaic thermal system (PVT) from energy and exergy viewpoints". Energy, vol. 138, pp. 682-95, 2017.

[30] M. Ghadiri, M. Sardarabadi, M. Pasandideh-Fard, AJ. Moghadam AJ. "Experimental investigation of a PVT system performance using nano ferrofluids". Energy Convers Manage, vol. 103, pp. 468-76, 2015.

[31] MS. Hossain, AK. Pandey, J. Selvaraj, NA. Rahim NA, MM. Islam, VV. Tyagi. "Two side serpentine flow based photovoltaic-thermal-phase change materials (PVT-PCM) system: Energy, exergy and economic analysis". Renewable Energy, vol. 136, pp. 1320-36, 2019.

[32] M. Hosseinzadeh, M. Sardarabadi, M. Passandideh-Fard. "Energy and exergy analysis of nanofluid based photovoltaic thermal system integrated with phase change material”. Energy, vol. 147, pp. 636-47, 2018.

[33] B. Agrawal, GN. Tiwari. "Optimizing the energy and exergy of building integrated photovoltaic thermal (BIPVT) systems under cold climatic conditions". Appl Energy, vol. 87, 417-26, 2017.

[34] M. Khaki, A. Shahsavar, S. Khanmohammadi, M. Salmanzadeh. "Energy and exergy analysis and multi-objective optimization of an air based building integrated photovoltaic/ thermal (BIPV/T) system". Sol Energy, vol. 158, pp. 380-95, 2017.

[35] A. Buonomano, F. Calise, A. Palombo, M. Vicidomini. "Transient analysis, exergy and thermo-economic modelling of façade integrated photovoltaic/thermal solar collectors". Renewable Energy, vol. 137, pp. 109-26, 2019.

[36] A. Fudholi, et al., "Energy and Exergy Analyses of Photovoltaic Thermal Collector with $\nabla$-groove," Solar Energy, vol. 159, pp. 742-50, 2018.

[37] P. Nag, "Basic and Applied Thermodynamics," New Delhi, India: Tata McGrawHill, 2002.

[38] T. Tadese and G. Tesema, "Energy, Entropy and Exergy Concepts: Thermodynamic Approach, A Critical Review," Abhinav National Monthly Refereed Journal of Research in Science \& Technology, vol. 3, no.5, 2014.

[39] A. Fudholi, et al., "Performances and Improvement Potential of Solar Drying System for Palm Oil Fronds," Renewable Energy, vol. 78, pp. 561-65, 2015.

[40] M. Hazami, et al., "Energetic and Exergetic Performances Analysis of a PV/T (Photovoltaic Thermal) Solar System Tested and Simulated Under to Tunisian (North Africa) Climatic Conditions," Energy, vol. 107, pp. 78-94, 2016.

[41] M.E.A.Slimani, et al., "Study and Modeling of Energy Performance of A Hybrid Photovoltaic/Thermal Solar Collector: Configuration Suitable For an Indirect Solar Dryer," Energy Conversion and Management, vol. 125, pp. 209-21, 2016.

[42] C.S. Rajoria, et al., "Exergetic and Enviroeconomic Analysis of Novel Hybrid PVT Array," Solar Energy, vol. 88, pp. 110-19, 2013.

[43] B. Agrawal \& G.N. Tiwari, "Optimizing the Energy and Exergy of Building Integrated Photovoltaic Thermal (BIPVT) Systems Under Cold Climatic Conditions," Applied Energy, vol. 87, pp. 417-26, 2010.

\section{BIOGRAPHIES OF AUTHORS}
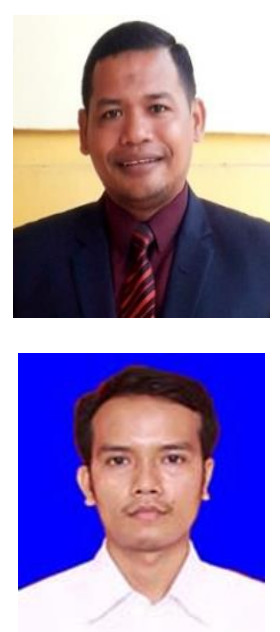

Bahtiar is currently a physic lecturer the State Islamic University (UIN) Mataram, Lombok, Indonesia. His Ph.D degree was obtained in from State University of Surabaya, Indonesia at 2016 in the field of Physic education. He took his Master degree of Physic education at State University of Yogyakarta. He actively conducts research in physic and physic education. He published many articles in national and international journals. He was a speaker at Mathematic-Informatics-Science-Education International-Conference (MISEIC) 2017, 2018 by FMIPA State University of Surabaya and international Conference on Environmental and Science Education (ICESE) 2019 by FMIPA State University of Semarang

Muhammad Zohri obtained his S.Si (2009) in physics and received the Master of Science degree in Solar Energy Research Institute from The National University of Malaysia, Malaysia in 2017, with a thesis based on PVT system. He was appointed a Graduate Research Assistant (GRA) under Dr. Ahmad Fudholi in Solar Energy Research Institute (SERI) in UKM Malaysia, during his master's degree. He worked at State Islamic University (UIN) Mataram, Indonesia. He was a speaker at The 2nd International Symposium on Current Progress in Mathematics and Science (2nd ISCPMS) FMIPA UI in Depok and The 4th Solar Energy Research Institute (SERI) Colloquium 2016, in UKM Bangi, Malaysia. He has published many paper in Scopus and WoS Index. 


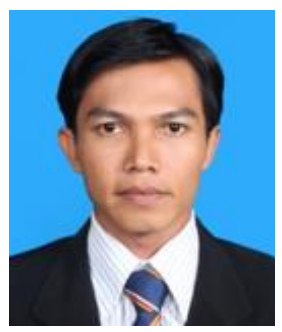

Ahmad Fudholi obtained his S.Si (2002) in physics. He has working experience for about 4 years (2004-2008) as Head of the Physics Department at Rab University Pekanbaru, Indonesia. A. Fudholi started his master's course in Energy Technology (2005-2007) at Universiti Kebangsaan Malaysia (UKM). After his master, he became Research Assistant at UKM up to 2012. After his Ph.D. (2012) he became a Postdoctoral in Solar Energy Research Institute (SERI) UKM up to 2013. He joined the SERI as a Lecture in 2014. More than USD 304,000 research grant in 2014-2017 obtained. More than 25 M.Sc projects supervised and completed. Until now, he managed to supervise $6 \mathrm{Ph} . \mathrm{D}$. (5 main supervisors and 1 Co. supervisor), 2 Master's student by research mode, and 5 Master's student by coursework mode, he was also as examiner (3 Ph.D. and 1 M.Sc). His current research focuses on renewable energy, especially energy technology. He has published more than 100 peer-reviewed papers, which 25 papers in ISI index (20 Q1, impact factor more than 3 ) and more than 48 papers in Scopus index, 10 more currently accepted manuscript, 20 more currently under review, and 2 book chapters. Additionally, he has published more than 70 papers in international conferences. His total citations of 571 by 395 documents and h-index of 12 in Scopus (Author ID: 57195432490). His total citations of 1093 and h-index of 19 in google scholar. He is appointed as a reviewer of high impact journals such as Renewable and Sustainable Energy Reviews, Energy Conversion and Management, Applied Energy, Energy and Buildings, Applied Thermal Engineering, Energy, Industrial Crops and Products, etc. He is appointed as a reviewer of reputed journals such as Drying Technology, International Journal of Green Energy, Drying Technology, Biosystem Engineering, Journal of Sustainability Science and Management, Journal of Energy Efficiency, Sains Malaysiana, Jurnal Teknologi, etc. He is also appointed as editor journals. He has received several awards such as Gold Medal Award at the International Ibn Al-Haytham's Al-Manazir Innovation and Invention Exhibition 2011, Silver Medal Award at the International Technology EXPO (ITEX) 2012, Silver Medal Award at the Malaysia Technology Expo (MTE) 2013, Bronze Medal Award at International Exposition of Research and Invention (PECIPTA) 2011, also 2 Bronze Medal Award at PECIPTA 2017. He was also invited as speaker: Workshop of Scientific Journal Writing; Writing Scientific Papers Steps Towards Successful Publish in High Impact (Q1) Journals 